\title{
1-aminocyclopropane-1-carboxylate oxidase 2 reduction effects on physical and physiological responses of Eksotika papaya
}

\begin{abstract}
The Malaysian Eksotika papaya (Carica papaya L.) has poor keeping quality due to its fast ripening attribute, which leads to post-harvest losses. This study is aimed at extending the shelf life of this perishable Eksotika fruit using antisense technology. A total of 6,000 Eksotika somatic embryogenic calli was transformed with the antisense 1aminocyclopropane-1-carboxylic acid oxidase 2 gene (ACO2) construct, and 46 PCRpositive putative transformants were obtained. Gene expression analysis using real-time PCR on the 46 regenerated putative transgenic lines revealed that 42 showed down-regulation of the ACO2 gene with two- to five-fold differences among the lines. Out of 22 independently selected transformed lines grown under net house conditions, 16 harbored a single copy of the transgene. Physical stature of the transgenic plants was not significantly different from that of the non-transformed seed-derived papaya plants. Physiological evaluations of the transgenic fruits showed a 15-day delay in ripening compared with 4 days of the nontransformed seed-derived papaya fruits. The total soluble solid (TSS) of the transgenic fruits was comparable to that of the non-transformed seed-derived fruits with similar $11-15^{\circ}$ Brix, implying the transgenes did not affect the TSS content.
\end{abstract}

Keyword: Agrobacterium tumefaciens; Antisense; Delayed ripening; Genetic engineering; Shelf-life 